\title{
Engaging Faculty In Community Engagement
}

\author{
Glynis A Fitzgerald, Central Connecticut State University, USA
}

\begin{abstract}
Researchers endorse the integration of community engagement (CE) into higher education as a way to improve the relevance of education, address community needs, and forge universitycommunity partnerships (Zlotkowski, 1996). CE can help create stronger ties between universities and their communities and provide students with experiential learning and an opportunity to practice new skills. Successful integration of $C E$ in the curriculum can assist universities in achieving their mission. The question is how to communicate these benefits to the faculty of a university and how the university can support CE in an organized way. This paper reports on factors contributing to successful implementation of community engagement in higher education. A case study of one university is presented and comparisons with universities, which have successfully implemented CE into their campus culture, are also made. Key principles identified include mentoring, awareness-raising, and supportive university infrastructure.
\end{abstract}

Keywords: Community Engagement; Volunteerism

\section{INTRODUCTION}

ommunity Engagement is defined as a university's active role in supporting a mutually beneficial relationship with on- and off-campus community partners in a range of ways. One faculty member defined $\mathrm{CE}$ as "a meaningful and mutually beneficial collaboration with partners in education, business, and public and social service. It involves using that aspect of teaching which enables learning beyond the campus walls, that aspect of research which makes what we discover useful beyond the academic community, and that aspect of service which directly benefits the public."

Using this approach, engagement has taken the form of student teaching, internships and volunteer work, as well as more civically focused endeavors. Students in these experiences are learning valuable 'real world' lessons, testing out concepts learned in the classroom, and often obtaining leadership skills. Communities, likewise, have benefited from the time and talent expended by students and faculty (Bonsall, Harris, \& Marczak, 2002). Universities, as a whole, find advantages as well. Mayfield (2001) suggests that engaged universities are better able to integrate the teaching, research and service functions of the institution; fulfill the function of the academy in society and, if necessary, deflect criticism that universities take public support but ignore the concerns of the community.

While the benefits of $\mathrm{CE}$ are great, many academics do not view $C E$ as a priority in their work. Combining community service and academic courses, while successfully accomplishing service goals and achieving learning outcomes, is challenging. Many faculty are concerned that the accomplishment of CE goals may come at the sacrifice of achieving more traditional scholarly goals and vice versa.

\section{HISTORICAL ROOTS OF COMMUNITY ENGAGEMENT}

In 1987 Ernest Lynton and Sandra Elman published New Priorities for the University, a landmark book about the importance of university faculty and student work in the community. The authors believe that a university needs to perform three functions if it is to work effectively with the community - an information/communication function, a brokering/negotiation function, and a delivery function. The authors stated that universities pursuing this 
mission will need to adapt staffing and promotion/tenure criteria and create incentives for faculty engagement and mechanisms for multidisciplinary collaboration. They suggested that complexity, originality, innovativeness and thoroughness may be useful criteria for assessing faculty involvement in outreach projects.

In 1990 Ernest Boyer published a special report of the Carnegie Foundation entitled Scholarship Reconsidered that enlivened discussion about the importance of applied community-based work by university faculty and students. Boyer proposed that four forms of scholarship be recognized for promotion/tenure consideration - the scholarship of discovery (research), integration (multidisciplinary perspectives), application (community service), and teaching. He stated that (community) "service activities must be tied directly to one's special field of knowledge and relate to and flow out of this professional activity." He believed that it was "serious, demanding work requiring the rigor and accountability traditionally associated with research."

In 1999 a Kellogg Commission report on the Future of State and Land-Grant Universities concluded that "with the resources and superbly qualified professors and staff on our campuses, we can organize our institutions to serve both local and national needs in a more coherent and effective way." The Commission referred to institutions embracing this concept as "engaged institutions." Engaged institutions are responsive and accessible to the community, integrate community service with teaching and research, facilitate interdisciplinary work among faculty and students, and commit the necessary resources to make it happen. Stated recommendations to universities that wish to "engage" included making engagement a priority, encouraging multidisciplinary work, and creating new incentives for faculty to engage.

Further evidence that community outreach is an important issue in academia was offered by Academe, the bulletin of the American Association of University Professors (2000), that was devoted to "civic engagement and higher education." Several articles in this issue state that outreach activities are a catalyst for 1) service learning that provides students with opportunities to engage in civic work at a time when many segments of society are disengaging and 2) interdisciplinary activity among faculty at a time when universities tend to isolate individuals and ideas remain theoretical because they are not tested in real-world settings.

\section{CCSU}

Founded in 1849 as the New Britain Normal School, Central Connecticut State University (CCSU) is the oldest public institution of higher education in Connecticut. It is a comprehensive school offering degree programs in the liberal arts and sciences, teacher education, technology, and business through the master's level. Comprised of The School of Arts \& Sciences, The School of Education \& Professional Studies, The School of Technology, The School of Business, and The School of Graduate Studies, CCSU houses more than 35 departments. It enrolls approximately 12,000 students annually drawing heavily from the greater Hartford area.

CCSU is following the advice of the 1999 Kellogg Commission report by making community engagement a priority, encouraging multidisciplinary activity, and creating new incentives for faculty to engage in community outreach work.

According to its mission statement, revised in 2000 to include specific mention of outreach activities, "Central Connecticut State University is a community of learners dedicated to teaching and to scholarship" that "encourages the development and application of knowledge and ideas through research and outreach activities."

Despite the inclusion in the mission statement, CE was relatively unappreciated at the university. While engagement had long been one of the core components of the university's vision, it took a new provost to see that this goal was not fully being attended to. In his first address to the faculty, the Provost challenged those present to consider what the statement, "We prepare students to be thoughtful, responsible and successful citizens" meant and what we were doing to accomplish this statement of our vision.

At CCSU, as at other institutions, collaborations between the university/college and the community had been launched by individual units, faculty, and staff. Although individual faculty members had used community service experiences to enhance their courses, these efforts were not the norm and occurred with little notice and 
without the benefit of a supportive infrastructure. There was no unifying framework or infrastructure supporting this activity. Thus, a great deal of work went unrecognized and experiences and effective practices were not shared across the institution. In addition, duplicate and complementary activities were not identified or addressed and faculty and staff who desired to contribute their expertise were unaware of opportunities to do so. Of equal importance, leadership for advancing engagement was not fostered.

Several incentives were developed to encourage faculty to engage in outreach activities. First, a mechanism for supplementing faculty salaries for outreach work that is performed in addition to their normal workload is included in the faculty union contract. Second, the university president or designee, at their discretion and with agreement of relevant deans and department heads, can release faculty from teaching responsibilities by awarding "reassigned time" for engaging in administration and research activities. Informally, this has been broadened to include outreach activities. Departments can then be "reimbursed" for lost teaching effort with part-time adjunct faculty if needed. And third, based on Ernest Boyer's Scholarship Reconsidered, the distinct treatment of presentations and publications based on outreach activities as formal criteria for promotion/tenure evaluation is presently being considered.

Currently, these forms of scholarship may be folded into considerations of "university service", an established criterion for promotion/tenure. In some disciplines, presentations and publications based on outreach activities may be considered under "creative activities," which includes products of research and like-scholarship, or "professional activity," also established criteria for promotion and tenure. Discussions on faculty evaluation now include suggestions to persuade traditionalists that the quality of outreach activities can be judged and recognized as faculty endeavors worthy of consideration for promotion.

Several programs at CCSU are specifically designed to link the university with surrounding communities. The Continuing Education division of the university offers a large number of noncredit training programs. The School of Education operates a very successful Professional Development School (PDS) Network in which CCSU student interns and faculty advisors work closely with a large number of public schools. As at most universities, School of Business faculty are actively sought for their consultancy expertise. And faculty in the School of Arts and Science have spawned the Institute for Tourism \& Hospitality, the William A. O'Neill Center for Public Policy and Practical Politics, the Center for Social Research (CSR), and the Henry C. Lee Institute for the Study of Crime and Justice - all with strong community outreach agendas.

\section{NATIONALLY}

Ramaley (2000) estimates that while 10 to 15 percent of faculty are "committed to engagement," almost two thirds are interested but looking for institutional support or waiting to see if engagement will be a long-term university priority. For many faculty, disciplinary barriers to anything but traditional academic models limit venues for dissemination and thereby legitimate tenure and promotion options. Other faculty may express interest in engaged scholarship but lack institutional commitment and interdisciplinary infrastructure to support their work.

Researchers liken building an engaged campus to a maturation process that involves shared learning, shared language, creating infrastructure, expanding collaboration, creating policies and assessing effects (American Association for Higher Education, 2004). Lamb, Swinth, Vinton and Lee (1998) attributed much of the resistance to CE to the absence of an infrastructure for sustaining service efforts. They identified that the operational aspects, including identifying and nurturing connections, and assisting faculty and students, require infrastructure and financial commitment from the institution; but there are certainly other factors at play. One resistance identified at the subject university is the reluctance of some faculty to see this work as beneficial let alone as scholarly. The literature suggests that women are more likely than men to engage in CE (Abes, Jackson, and Jones, 2002; Antonio, Astin, and Cress, 2000). Boyte (2004) shows that prior experiences, both in and outside the classroom, effect ones perceptions of CE. The discipline in which one studies might also play a role (Abes, Jackson, and Jones, 2002; Antonio, Astin, and Cress, 2000).

In order to successfully engage faculty, efforts must include mentoring, awareness-raising, and supportive university infrastructure. 


\section{MENTORING}

Those involved with community engagement activities may benefit from mentoring and other such supportive structures. This is particularly important for those new to CE. Learning opportunities should be created which allow faculty, who are active in CE, to share their experiences. Many faculty received little formal feedback or mentoring from senior colleagues. They were disappointed not to find a long-anticipated, supportive community of senior scholars dedicated to CE. Tenure-track faculty members themselves were reluctant to seek assistance because doing so was tantamount to admitting a weakness.

Because the university provides administrative oversight on grants and contracts, faculty are much more willing to take on outreach projects. They are relieved not to have the responsibility of personnel issues (hiring, payroll, etc.), purchasing, budgets, financial reporting, etc. With the university's help in both preparing grant/contract proposals and monitoring projects, faculty are now more eager to search out projects in the community. As a result, CCSU is establishing long-term relationships and work commitments with several agencies and organizations.

\section{RAISING AWARENESS}

Communication strategies are essential to partnership formation to ensure sustainability and to enhance awareness of initiatives amongst the campus and community.

It is important for universities to use media to raise awareness of the activities and commitment to CE. Seed grants for CE initiatives also aid in raising awareness across the university and community. Universities should also seek to acknowledge, promote and even celebrate the CE efforts of faculty and students. Creating awareness in the community about CE is important. Word-of-mouth promotion of CE by top university administrators, past clients, and the CE advisory committee members are the most effective means of promoting CE on campus and in the community. A basic brochure and website are also necessary.

\section{SUPPORTIVE UNIVERSITY INFRASTRUCTURE}

Universities need to commit the time necessary to examining existing promotion and tenure practices to enhance the perception of usefulness of CE. They need to recognize the process of forming, developing and maintaining relationships and build processes that support such initiatives. Recently, the CSR along with several other Institutes/Centers affiliated with the School of Arts and Sciences were put under the administrative authority of a new special assistant to the president for external/public affairs. This should help avoid unnecessary duplication of efforts and needs, and facilitate a synergy that should help all programs (e.g., the CSR will provide project development/management assistance to other institutes/centers).

Many outreach projects are interdisciplinary - different perspectives/disciplines are brought to bear on one issue or problem. Not only does this yield a better outcome, and therefore benefit the client, but it has been a vehicle for bringing faculty together who would otherwise not have had contact on campus. Ernest Boyer defines the scholarship of integration as, "... making connections across the disciplines, placing the specialties in larger context, illuminating data in a revealing way, often educating nonspecialists, too." That is exactly what is happening at CCSU.

\section{CONCLUSION}

In conclusion, $\mathrm{CE}$ is of great value to universities, their faculty, students, staff and the community served. In order to fully engage faculty, universities need to provide the necessary structures, policies and communication to enable CE to fully reach its potential. Growing administrative support for outreach scholarship at CCSU is reflected by 1) change in the language of the university's mission statement to include specific mention of outreach activities and 2) current discussions about how presentations/publications by faculty (and their students) based on outreach activities can be judged as consideration for promotion. The ability to earn extra income above their regular pay is a major incentive for faculty to participate in outreach projects, especially junior faculty on entry-level salaries. The 
clause in the AAUP collective bargaining contract which permits faculty to be compensated for work performed in addition to their regular course work is vital to the success of CE projects.

CCSU has a long way to go before community outreach receives the same level of attention and support that teaching, research and university service functions receive. The benefits to faculty and students that outreach projects generate in terms of making their research and education more relevant is difficult to quantify and therefore difficult for some to comprehend.

\section{AUTHOR INFORMATION}

Glynis A Fitzgerald, Ph.D., Associate Professor of Communication, Assistant Dean of Graduate Studies, Central Connecticut State University, 1615 Stanley Street, New Britain, CT 06050. Telephone: (860) 832-2696, E-mail: fitzgeraldg@ccsu.edu.

\section{REFERENCES}

1. Abes, E. S., Jackson, G. , \& Jones, S. R. (2002) . Factors that motivate and deter faculty use of servicelearning. Michigan Journal of Community Service Learning, 9, 5-17.

2. American Association for Higher Education (AAHE). (2004). Campus progress: Supporting the scholarship of teaching and learning. Washington, DC: Stylus.

3. Antonio, A. L., Astin, H. S. \& Cress, C. H. (2000). Community Service in Higher Education: A Look at the Nation's Faculty. Review of Higher Education, 23(4), 373-397.

4. Bonsall, D. L. Harris, R.A., \& Marczak, J.N. (2002). The community as a classroom. New Directions for Student Services, 100, 85-95.

5. Boyte, H. C. (2004). Going Public: Academics and Public Life (Occasional Paper No. 10062). Dayton, Ohio: Charles F. Kettering Foundation.

6. Lamb, C. H., Swinth, R. L. Vinton, K.L. \& Lee, J. B. (1998). Integrating service learning into a business school curriculum. Journal of Management, 22, 637-655.

7. Mayfield, L. (2001). Town and gown in America: Some historical and institutional issues of the engaged university. Education for Health, 14, 231-240.

8. Ramaley, J. (2000). Nurturing an "Engaged University": One president's quest. In AAHE Bulletin 52 (7) March.

9. Zlotkowski, E. (1996). Opportunity for all: Linking service learning and business education. Journal of Business Ethics, 15, 5-19 
NOTES 